МІРОШНИК М. А., д. т. н., професор,

КЛИМЕНКО Л. А., к. т. н., доценТ

(Український державний університет залізничного транспорту)

\title{
Методи автоматизованого комп'ютерного цифрового пристрою локального управління
}

Подано метод автоматизованого комп'ютерного проектування циифрового пристрою локального управління (регулювання). На основі спрощеного алгоритму функціонування системи, поданого граф-схемою алгоритму (ГСА), складається автоматна модель у вигляді графа переходів кінцевого автомата Мілі. Граф переходів подано мовою опису апаратури VHDL в формі двопрочесорного автоматного шаблону. За графом переходів будується алгоритм діагностування пристрою управління за стратегією обходу всіх дуг графа, щзо гарантує його повноту. На підставі алгоритму діагностування будується VHDL-модель апаратного пристрою діагностування. Верифікація моделі розробленого пристрою діагностування виконується з використанням системи моделювання Active-HDL. Синтез пристрою управління і пристрою діагностування виконується за допомогою САПР XILINX ISE.

Ключові слова: діагностичні експерименти, керуючий автомат, граф переходів, синхронізуюча послідовність, CAПP, Active-HDL, XILINX ISE.

Постановка проблеми в загальному вигляді та їі зв'язок із важливими науковими чи практичними завданнями

Системи автоматичного регулювання (САР) призначені для підтримки постійної або зміни за заданим законом деякої керованої величини. Системи автоматичного керування (САК) здійснюють сукупний вплив на об'єкт, обраний з безлічі можливих впливів, спрямованих на досягнення певного критерію керування. У загальному випадку, САР і САК можуть будуватися як на основі локальних засобів автоматичного регулювання, так i 3 застосуванням цифрових систем автоматичного керування. Такі локальні системи, як правило, реалізуються на інтегральних схемах, виготовлених на замовлення, або мікроконтролерах.

Важливим завданням при побудові САК $\epsilon$ забезпечення надійності їх функціонування, що неможливо без використання автоматичних систем технічного діагностування. При проектуванні сучасних систем технічного діагностування широко використовуються комп'ютерні технології автоматизованого проектування з застосуванням мов опису апаратури і сучасної технологічної бази. Даний підхід дозволить реалізувати систему діагностування віддаленого пункту управління будь-якої енергетичної системи без участі людини і без відключення основної системи управління на тривалий час. Виходячи 3 огляду публікацій $з$ питання побудови вбудованих систем діагностування [1-3] можна зробити висновок, що питання побудови апаратних систем діагностування в локальних системах автоматичного управління виробничими процесами на сучасній технологічній базі потребують подальших досліджень.

Зараз досить поширені віддалені пункти управління, які працюють без або 3 мінімальною участю людини, а також без використання персональних комп'ютерів. При цьому пристрої управління реалізуються на технологічній базі МК (мікроконтролер), ASIC (application-specific integrated circuit, (інтегральна схема спеціального призначення)) або ПЛІС (програмована логічна інтегральна схема). Незалежно від способу технічної реалізації зазначені системи реалізують оригінальний алгоритм управління, описаний відповідною граф-схемою. При цьому виникає проблема діагностики правильного функціонування керуючого пристрою без використання показників реальних датчиків, тому що ïх включення в режим діагностування може порушити процес функціонування критичних систем електроенергетики та газопостачання. Процес діагностування керуючого пристрою має йти в автономному режимі при відключенні систем управління на досить короткий час. Тому актуальною $\epsilon$ задача розробки автоматичних апаратних засобів діагностування, які працюють в автономному режимі без участі людини і гарантують задану повноту діагностування. 
І Н Ф О Р М А Ц Й Н О - К Е Р У Ю Ч І С И С Т Е М И Н А 3 А Л І З Н И Ч Н О М У Т Р А Н С П О Р Т І

Наукова новизна роботи полягає в подальшому розвитку методів автоматизованого комп'ютерного проектування цифрового пристрою локального управління.

\section{Аналіз останніх досліджень і публікацій, в яких започатковано розв'язання даної проблеми і на які спирається автор}

Одним 3 важливих аспектів підвищення ефективності та надійності систем $є$ автоматизація їх технологічних процесів і процесів управління. В [1] розглянуті питання автоматизації об'єктів, відображені питання теорії систем управління і правила побудови систем автоматизації. Складовою частиною сучасних систем автоматичного управління є блоки цифрового управління, які реалізують задані алгоритми управління, подані, як правило, у вигляді граф-схем алгоритмів (ГСА). Зазначені блоки управління реалізуються на технологічній базі мікроконтролерних систем, в замовних великих інтегральних схемах (BIC) або програмованих логічних інтегральних схемах (ПЛІС)

У роботах [2-4] запропоновані методи проектування пристроїв цифрового управління на основі кінцевих автоматів, поданих у вигляді ГСА. В [2] запропоновано методи логічного синтезу і схемної реалізації автоматів Мілі і Мура на основі ПЛІС або БIC ASIC. В [3] розглянуто методи логічного синтезу і оптимізації композиційних мікропрограмних пристроїв керування, описаних лінійними ДСА, методи оптимального кодування станів автоматів по ДСА з урахуванням конкретної архітектури ПЛІС та питання реалізації кінцевих керуючих автоматів Мура на основі ПЛІС FPGA 3 урахуванням оптимізації кількості логічних осередків LUT (look-up table). В [4] показано застосування цифрових САУ в управлінні рухомим об'єктом 3 використанням інтернеттехнологій і хмарних сервісів, а в [5] розглянуто застосування методів технічної діагностики і неруйнівного контролю в теплогазопостачанні на основі аналізу електричних, газодинамічних та теплових показників. Важливою характеристикою надійної роботи цифрових САУ $є$ діагностування самого алгоритму управління на логічному рівні. Створення діагностичної інфраструктури локальних цифрових САУ, побудованих за технологією системна-кристалі (SoC, System on Chsp), подано в [6], розглянуто питання побудови діагностичної інфраструктури розподілених систем обробки інформації та управління на основі ПЛІС. Питання автоматизації проведення діагностичних експериментів (ДЕ) над моделями кінцевих автоматів мовами опису апаратури (HDL, Hardware Description Language) розглянуто в [7]. Розглянуто процедури організації ДЕ в системі верифікації САПР цифрових пристроїв (ЦУ). Питання автоматизації проведення ДЕ над HDL-моделями кінцевих автоматів у формі автоматного шаблону розглянуто в [8]. Розглянуто процедури організації ДЕ в системах автоматизації проектування (САПР) і верифікації на основі ПЛІС. Важливим розділом в проектуванні і діагностуванні цифрових систем $є$ тестопридатності проектування (DFT, Design For Test).

Виділення невирішених раніше частин загальної проблеми, яким присвячується означена стаття

Виходячи 3 огляду публікацій, можна зробити висновок, що питання побудови апаратних систем діагностування в локальних системах автоматичного управління на сучасній технологічній базі потребують подальших досліджень. Досить поширені віддаленіші території управління, які працюють без або 3 мінімальною участю людини, а також без використання персональних комп'ютерів. При цьому пристрої управління реалізуються на технологічній базі мікроконтролерів, ASIC або ПЛІС. Незалежно від способу технічної реалізації зазначені системи реалізують оригінальний алгоритм управління, описаний відповідно граф-схемою. При цьому виникає проблема діагностики правильного функціонування саме пристроїв управління без використання показань реальних датчиків, тому що їх включення в режим діагностування може порушити процес функціонування критичних систем електроенергетики та газопостачання. Процес діагностування пристрою управління повинен йти в автономному режимі при відключенні основних систем управління на досить короткий час. Тому актуальною с задача розробки автоматичних апаратних засобів діагностування, які працюють в автономному режимі без участі людини i гарантують задану повноту діагностування.

Формулювання цілей статті (постановка завдання)

Метою даної роботи є розробка автоматизованої моделі апаратної системи діагностування пристроїв управління, подання цієї моделі мовами опису апаратури та їх реалізація на технологічній платформі ПЛІС.

\section{Виклад основного матеріалу дослідження 3 повним} обгрунтуванням отриманих наукових результатів

\section{1 Стратегія діагностування керуючого автомата}

ДЕ над HDL-моделлю кінцевого автомата полягає в подачі на неї вхідних впливів, відповідно до обраної стратегії обходу змістовного графа переходів, отриманні вихідних реакцій на Waveform i порівнянні отриманих реакцій 3 еталоном. На підставі цього робиться висновок про відповідність HDL-моделі специфікації. ДЕ проводиться 3 використанням системи верифікації HDL-моделей (TestBench) в середовищі проектування Active-HDL. При проведенні 
ДЕ в простих HDL-моделях КА подача вхідних впливів і порівняння отриманих реакцій $з$ еталонами не являє особливих труднощів, навіть в режимі візуального порівняння з Waveform, так як тестові дані подаються безпосередньо на входи автомата, а реакції знімаються з його виходів.

На підставі стратегії обходу всіх дуг графа КА (рис. 1) будується алгоритм діагностування 3 гарантованою повнотою щодо одиночних помилок переходів (наприклад, перехід а1 - а2 замість а1 - а3), поданий на рис. 1 у вигляді бінарного дерева рішень [5].

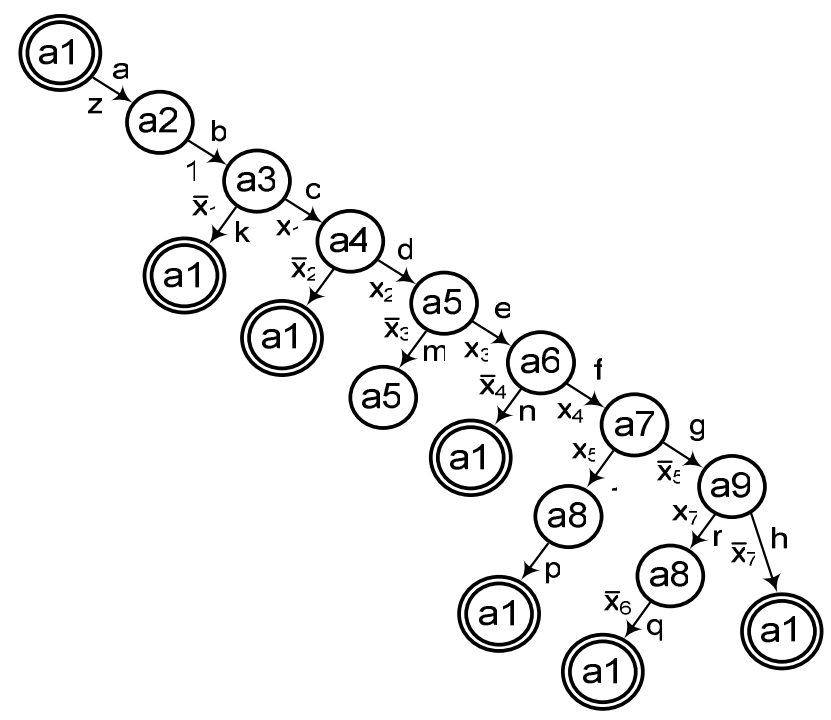

Рис. 1. Дерево рішень для графа переходів КА

По дереву рішень будуються варіанти обходу дуг графа. При цьому слід враховувати, що проводиться так званий «неруйнівний ДЕ», коли обхід дуг графа починається 3 початкової вершини i в ній же закінчується. Варіанти обходу графа переходів КА подано на рис. 2.

$$
\begin{aligned}
& \mathrm{a} 1-\mathrm{a} 2-\mathrm{a} 3-\mathrm{a} 1 \\
& \mathrm{a} 1-\mathrm{a} 2-\mathrm{a} 3-\mathrm{a} 4-\mathrm{a} 1 \\
& \mathrm{a} 1-\mathrm{a} 2-\mathrm{a} 3-\mathrm{a} 4-\mathrm{a} 5-\mathrm{a} 6-\mathrm{a} 1 \\
& \mathrm{a} 1-\mathrm{a} 2-\mathrm{a} 3-\mathrm{a} 4-\mathrm{a} 5-\mathrm{a} 6-\mathrm{a} 7-\mathrm{a} 8-\mathrm{a} 1 \\
& \mathrm{a} 1-\mathrm{a} 2-\mathrm{a} 3-\mathrm{a} 4-\mathrm{a} 5-\mathrm{a} 6-\mathrm{a} 7-\mathrm{a} 9-\mathrm{a} 1 \\
& \mathrm{a} 1-\mathrm{a} 2-\mathrm{a} 3-\mathrm{a} 4-\mathrm{a} 5-\mathrm{a} 6-\mathrm{a} 7-\mathrm{a} 9-\mathrm{a} 8-\mathrm{a} 1
\end{aligned}
$$

\section{Рис. 2. Варіанти обходу графа переходів КА}

Варіанти обходу графа переходів КА заносяться в енергонезалежну пам'ять i використовуються при проведенні ДЕ з використанням апаратного пристрою діагностування.

\section{2 Структура та алгоритм пристрою діагностування}

При діагностуванні керуючого пристрою (КП), що працює 3 механічними, електричними, термодинамічними датчиками, виникає проблема реалізації вхідних значень електричної напруги, тиску, температури. Виходячи 3 цього пропонується імітувати вихідні значення відповідних датчиків в двійковому алфавіті $\{0,1\}$ (1 - параметр знаходиться в заданому допустимому інтервалі, 0 - параметр вийшов за межі допустимих значень).

Таким чином, пропонується апаратна реалізація пристрою діагностування (ПД), яке забезпечує виконання всіх переходів по графу керуючого автомата (КА), тобто фактично реалізує його пряму структурну таблицю. Структурну схему об'єкта керування 3 пристроєм діагностування подано на рис. 3, де КП - керуючий пристрій; ОК - об'єкт керування; ПД - пристрій діагностувания; РгД регістр даних, куди заноситься черговий варіант обходу графа; Y - керуючі сигнали; XX сповіщувальні сигнали об'єкта керування (в нашому випадку логічно оброблені показники датчиків); X сповіщувальні сигнали для керуючого пристрою; УХ YX - «імітація» сповіщувальних сигналів пристроєм діагностування; TM (test mode) - режим роботи приладу (ТМ=0 - робота в режимі керування, ТМ= 1 робота в режимі діагностування).

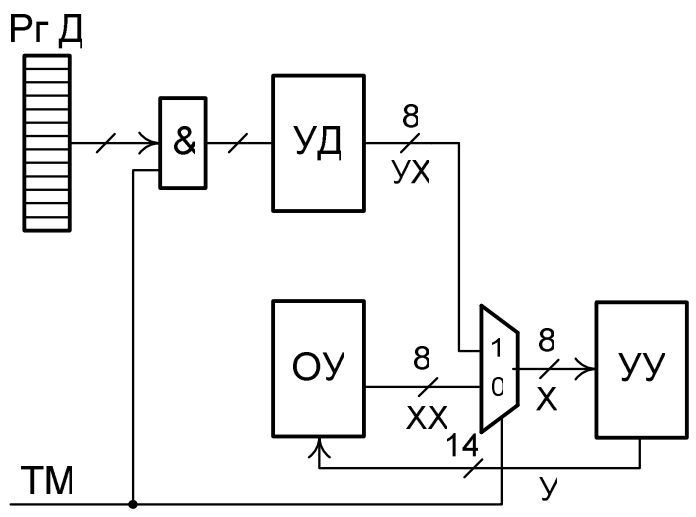

Рис. 3. Апаратний пристрій діагностування

Суть проведення діагностичного експерименту 3 використанням ПД полягає в наступному. При підготовці ДЕ будуються шляхи обходу графа переходів КА. При ТМ = 1 на вхід ПД надходить послідовність станів автомата (рис. 2), переходи в які необхідно перевірити (порядок опитування відповідних датчиків, який позначається при подачі в КП масивом X), і на виході ПД буде формуватися послідовність сповіщувальних сигналів YX, які «імітують» роботу об'єкта керування (ОК). Сигнали YX через мультиплексор надходять на КП (в форматі сповіщувальних сигналів $\mathrm{X}$, що надходять 3 об'єкта управління) та ініціюють його роботу. Керуючий пристрій, у свою чергу, формує вихідні сигнали Y, які надходять на ОК. Вихідні сигнали Y або порівнюються 
3 еталонами (якщо такі $\epsilon$ ) в режимі відключених датчиків, або, відповідним чином, відображаються на панелі індикації. Якщо послідовність Ү збігається 3 еталоном або індикація відображається правильно, то КП працює коректно.

Розглянемо реалізацію алгоритму діагностування. У ньому реалізується модифікована пряма структурна таблиця КА, яку подано на рис. 4.

\begin{tabular}{|l|l|l|l|}
\hline state & nextstate & $\mathrm{X}$ & $\mathrm{YX}(0-7)$ \\
\hline $\mathrm{a} 1$ & $\mathrm{a} 2$ & $\mathrm{Z}=1$ & 10000000 \\
\hline $\mathrm{a} 2$ & $\mathrm{a} 3$ & 1 & 00000000 \\
\hline \multirow{2}{*}{$\mathrm{a} 3$} & $\mathrm{a} 4$ & $\mathrm{X} 1=1$ & 01000000 \\
\cline { 2 - 4 } & $\mathrm{a} 1$ & $\mathrm{X} 1=0$ & 00000000 \\
\hline \multirow{2}{*}{$\mathrm{a} 4$} & $\mathrm{a} 5$ & $\mathrm{X} 2=1$ & 00100000 \\
\cline { 2 - 4 } & $\mathrm{a} 1$ & $\mathrm{X} 2=0$ & 00000000 \\
\hline \multirow{2}{*}{ a5 } & $\mathrm{a} 6$ & $\mathrm{X} 3=1$ & 00010000 \\
\cline { 2 - 4 } & $\mathrm{a} 5$ & $\mathrm{X} 3=0$ & 00000000 \\
\hline \multirow{2}{*}{$\mathrm{a} 6$} & $\mathrm{a} 7$ & $\mathrm{X} 4=1$ & 00001000 \\
\cline { 2 - 4 } & $\mathrm{a} 1$ & $\mathrm{X} 4=0$ & 00000000 \\
\hline \multirow{2}{*}{$\mathrm{a} 7$} & $\mathrm{a} 8$ & $\mathrm{X} 5=1$ & 00000100 \\
\cline { 2 - 4 } & $\mathrm{a} 9$ & $\mathrm{X} 5=0$ & 00000000 \\
\hline \multirow{2}{*}{$\mathrm{a} 8$} & $\mathrm{a} 1$ & $\mathrm{X} 6=0$ & 00000000 \\
\cline { 2 - 4 } & $\mathrm{a} 1$ & $\mathrm{X} 6=1$ & 00000010 \\
\hline \multirow{2}{*}{ a9 } & $\mathrm{a} 8$ & $\mathrm{X} 7=1$ & 00000001 \\
\cline { 2 - 4 } & $\mathrm{a} 1$ & $\mathrm{X} 7=0$ & 00000000 \\
\hline
\end{tabular}

Рис. 4. Реалізація алгоритму діагностування

Схемна реалізація КП може здійснюватися кількома способами, в залежності від способу кодування вхідної послідовності станів автомата при обході графа переходів.

1. Бітове кодування алгоритму діагностування.

За варіантом 1, послідовність станів автомата, відповідна черговому варіанту обходу графа переходів КП, кодується бітовим масивом, кожна ланка якого відповідає стану. Якщо біт стану дорівнює 1, то перехід відбувається до наступного стану, позначеного 1. Перехід між станами описаний у вигляді звичайного двопроцесного шаблону. Наприклад, якщо $\mathrm{D}(2)=1$ (D(2) відповідає стану A2, то наступним станом і буде A2. Нуль в ланці масиву відповідає поверненню в початковий стан.

2. Алгоритм діагностування за кодами станів автомата.

За варіантом 2, опис КП приймає на вхід масив чотирирозрядних чисел, кожне 3 яких є описом стану (наприклад «0001» відповідає стану А1 і тощо). Як тільки виявлено вектор подальшого стану, який дорівнює початковому («0001»), то послідовність вважається завершеною і відбувається повернення в початковий стан. Якщо виявлена послідовність не є кінцевою ланкою масиву, то наступні ігноруються. Перехід між станами аналогічний першому варіанту.
3. Алгоритм діагностування 3 використанням регістру зсуву.

Варіантом $3 €$ КП, що приймає на вхід масив чотирирозрядних чисел, кожне 3 яких є описом стану. Перший процес відповідає за копіювання вхідного масиву в проміжний і присвоєння початкових значень сигналам поточного (вихідного - A1) і подальшого станів 3 вхідного масиву (для того щоб виключити подвійне присвоєння одних і тих же значень). Після присвоєння сигналам початкових значень 3 переднім фронтом синхросигналу відбувається зсув вліво на один елемент масиву та присвоєння одиниці для уникнення переходів, які не відповідають послідовності. Якщо наступний стан рівний вихідному (початковому - A1), то послідовність вважається завершеною.

Апаратурні витрати по синтезу різних варіантів моделей ПД засобами CAПР XILINX ISE в ПЛІС Spartan 3E наведені в таблиці 1.

Таблиця 1

Результати синтезу ПД (Device utilization summary)

\begin{tabular}{|l|l|l|l|}
\hline $\begin{array}{c}\text { Selected Device : } \\
\text { 3s500efg320-5 }\end{array}$ & $\begin{array}{l}\text { Bapiaнt } 1 \\
\text { Number of Slices }\end{array}$ & $\begin{array}{l}\text { Bapiaнt out } \\
2\end{array}$ & $\begin{array}{l}\text { Bapiaнt } 4656 \\
\text { out } \\
\text { of } 4656\end{array}$ \\
\hline $\begin{array}{l}\text { Number of Slice } \\
\text { Flip Flops }\end{array}$ & $\begin{array}{l}16 \text { out } \\
\text { of 9312 }\end{array}$ & $\begin{array}{l}16 \text { out of } \\
\text { of 9312 }\end{array}$ & $\begin{array}{l}35 \text { out of } \\
9312\end{array}$ \\
\hline $\begin{array}{l}\text { Number of } 4 \text { input } \\
\text { LUTs: }\end{array}$ & $\begin{array}{l}15 \text { out } \\
\text { of 9312 }\end{array}$ & $\begin{array}{l}21 \text { out } \\
\text { of 9312 }\end{array}$ & $\begin{array}{l}17 \text { out } \\
\text { of 9312 }\end{array}$ \\
\hline Number of IOs & 20 & 50 & 10 \\
\hline $\begin{array}{l}\text { Number of bonded } \\
\text { IOBs: }\end{array}$ & $\begin{array}{l}17 \text { out } \\
\text { of } 232\end{array}$ & $\begin{array}{l}39 \text { out } \\
\text { of } 232\end{array}$ & 10 \\
\hline IOB Flip Flops: & 7 & 28 & 10 \\
\hline Number of GCLKs & 1 & 1 & 1 \\
\hline
\end{tabular}

Аналіз результатів синтезу різних варіантів схемних реалізацій пристрою діагностування показав таке:

1. Апаратні витрати на реалізацію Пд за першим варіантом малі, але при такому способі кодування послідовності станів автомата виникають проблеми, якщо граф переходів є мультиграфом, тобто між парою вершин $є$ більше однієї дуги, переходи за якими визначаються різними сповіщувальними сигналами (для розглянутого автомата це пара станів а8 -a1).

2. В схемній реалізації ПД за третім варіантом $є$ приблизно в 2 рази більше тригерів (Slice Flip Flops), ніж в інших варіантах реалізації. Це обумовлено тим, що в цьому варіанті вхідний масив с_Test_sequence копіюється в регістр DD, що фактично імітує роботу з зовнішньою енергонезалежною пам'яттю.

3. 3 точки зору масштабованості Пд щодо числа станів автомата, третій варіант схемної реалізації $\epsilon$ кращим, тому що зі збільшенням довжини 
послідовності для обходу графа автомата апаратні витрати в цьому варіанті зростають в незначній кількості, чого не можна сказати про другий варіант.

4. Апаратні витрати на УД при першій-ліпшій нагоді схемної реалізації можна порівняти 3 апаратними витратами на КП (табл.2), що підтверджує правильність обраної методики побудови апаратного пристрою діагностування.

3 Загальна модель керуючого пристрою i вбудованого пристрою діагностування

З'єднання керуючого пристрою i пристрою діагностування $€$ певна система управління i діагностування пристрою або навіть окремої системи. КП може працювати окремо від ПД, займаючись контролем роботи системи або пристрою, у вигляді подачі вихідних сигналів, що ініціюють виконання операцій. Використання повної системи управління і діагностування $\epsilon$ тестовим режимом перевірки поведінки пристрою або системи.

У лістингу 1 подано фрагмент HDL-коду, що описує дану систему. Це структурна модель, яка складається 3 двох компонентів. Компонент КП пов'язаний 3 компонентом ПД регістром X. Це вихідний масив ПД і вхідний масив КП для генерації значень перевірки умов.

Лістинг 1 - Опис структурної моделі КП та ПД

entity Workstation is port(

clk,reset : in STD_LOGIC;

Y:out STD_LOGIC_VECTOR(1 to 14 )

)

end Workstation;

architecture Workstation of Workstation is

component GAS_FSM is

port(

clk: in STD_LOGIC;

reset: in STD_LOGIC;

$\mathrm{X}$ : in STD_LOGIC_VECTOR (0 to 7);

Y: out STD_LOGIC__VECTOR (1 to 14 )

)

end component GAS_FSM;

component GAS_Diagnostic_Device is

port(

clk: in STD_LOGIC;

reset: in STD_LOGIC;

Yx: out STD_LOGIC_VECTOR (0 to 7)

)

end component GAS_Diagnostic_Device;

signal Yx:STD_LOGIC_VECTOR(0 to 7); begin

UUT0:GAS_Diagnostic_Device

UUT2:GAS_FSM port $\operatorname{map}(\mathrm{clk}=>\mathrm{clk}$,reset $=>$ reset, $\mathrm{Yx}=>\mathrm{Yx})$;

end Workstation;

port $\operatorname{map}(\mathrm{clk}=>\mathrm{clk}$,reset=>reset,X=>Yx, $\mathrm{Y}=>\mathrm{Y})$;

Побудовані VHDL-моделі керуючого i діагностичного автоматів повинні бути верифіковані інструментальними засобами системи моделювання Active-HDL. Результати верифікації аналізуються за діаграмою часу (waveform), на якій візуально відображається закон функціонування зазначених автоматів. На рис. 5 подано результат моделювання роботи ПД з реалізації варіанта обходу графа а1 - a2 a3 - a4 - a5 - a6 - a1. Результат порівняння роботи КП i ПД подано на рис. 6 , а на рис. 7 подано повну

Waveform 3 реалізацією алгоритму діагностування (послідовність А1-А2-А3-A4-А5-А6-А1), що підтверджує їх повну ідентичність. 
І Н Ф О Р М А Ц Й Н О - К Е Р У Ю Ч І С И С Т М И Н А 3 А Л І 3 Н ИЧ Н О М У Т Р А Н П О Р Т І

\begin{tabular}{|c|c|c|c|c|c|c|c|c|c|c|}
\hline Signal name & & Value & & & . & 2000 & . & 400 & . & ' \\
\hline ⿴囗十 r State & Сигналы & уд & 6 & $\bar{U}$ & $\overline{11}$ & $\overline{28}$ & 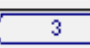 & 4 & $\overline{5}$ & $\bar{~} 6$ \\
\hline 田 $\mathrm{N}$ NextStat & & & 1 & $\mathrm{U}$ & 2 & 3 & 4 & 5 & 6 & $X 1$ \\
\hline$\boxplus \rightarrow Y X$ & & & 00 & 00 & 80 & 00 & 40 & 20 & 90 & Xou \\
\hline ⿴囗十 $X$ & овкод уди, & и вход уу & 00 & 00 & 80 & 00 & 40 & 20 & 10 & $\times 00$ \\
\hline$\boxplus \rightarrow Y$ & Результат & & 0010 & & 2000 & 1000 & 0800 & 0400 & 0200 & $\longdiv { 0 0 1 0 }$ \\
\hline$\boxplus л$ State & Сигналь & b yy & 6 & U & 1 & 2 & 3 & 4 & 5 & X6 \\
\hline$\exists$ Æ NextStat & & & 1 & $\mathrm{U}$ & 2 & 3 & 4 & 5 & 6 & $X 1$ \\
\hline
\end{tabular}

Рис. 5. Детальний опис сигналів структурної моделі

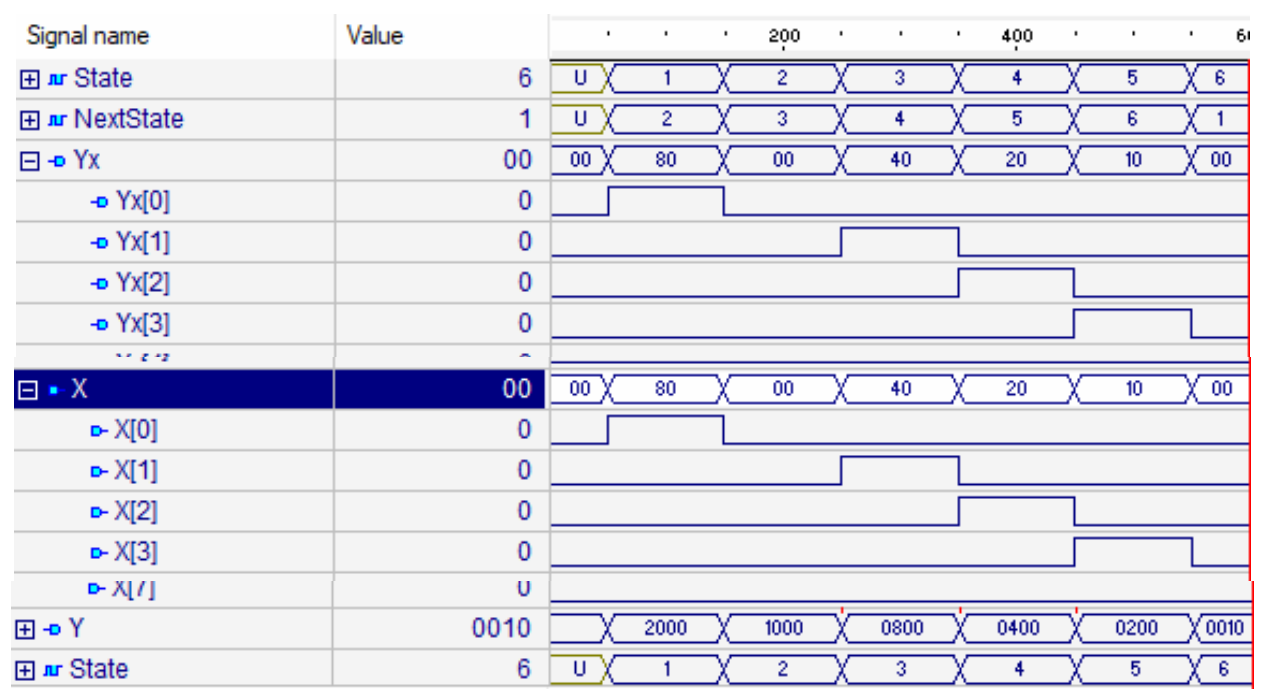

Рис. 6. Порівняння виходу ПД та входу КП

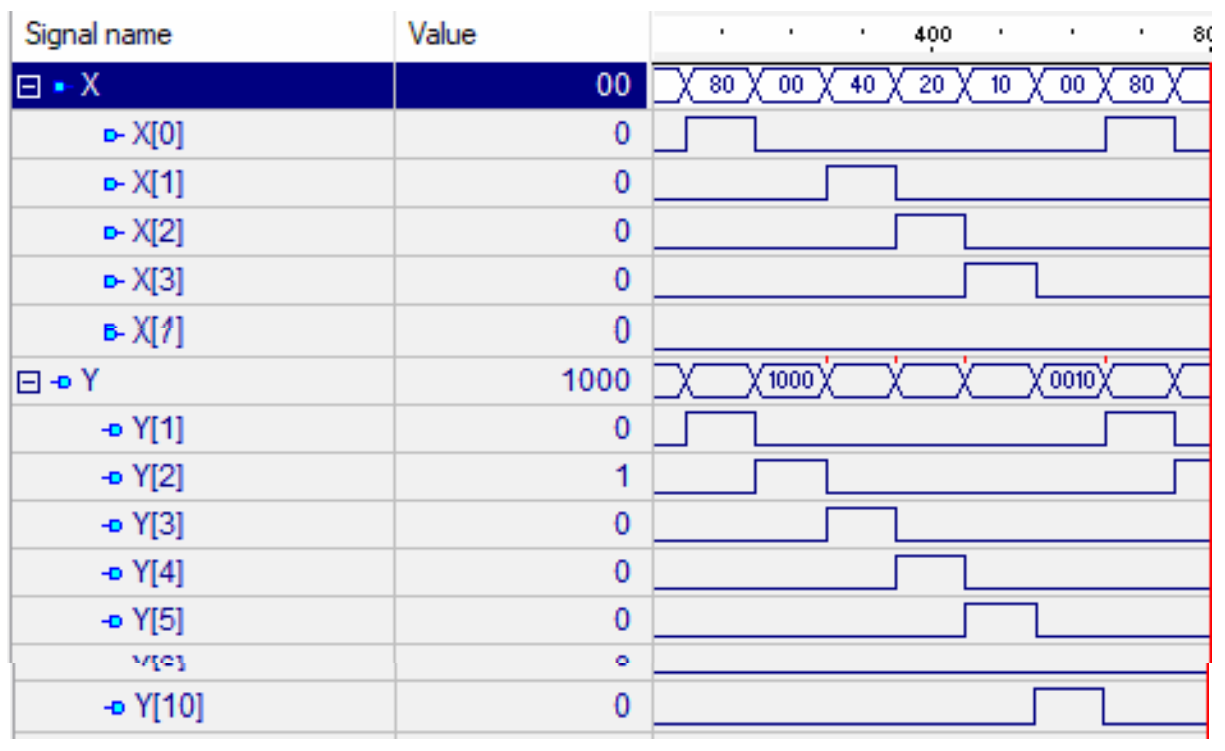

Рис. 7. Результат роботи пристроїв керування та діагностування

Загальні апаратні витрати по синтезу моделі КП і

ПД засобами САПР XILINX ISE в ПЛIC Spartan 3E

наведено в табл. 2. 
Таблиця 2

Результати синтезу по моделі КП і ПД

\begin{tabular}{|l|l|}
\hline Selected Device : 3s500efg320-5 & Bapiaнт 1 \\
\hline Number of Slices & 34 out of 4656 \\
\hline Number of Slice Flip Flops & 44 out of 9312 \\
\hline Number of 4 input LUTs: & 38 out of 9312 \\
\hline Number of IOs & 16 \\
\hline Number of bonded IOBs: & 17 out of 232 \\
\hline Number used as Shift registers: 1 & 1 \\
\hline Number of GCLKs & 1 \\
\hline
\end{tabular}

Висновки даного дослідження i перспективи подальшого розвитку у даному напрямку

У роботі подано метод автоматизованого комп'ютерного проектування цифрового пристрою локального управління. На основі спрощеного алгоритму функціонування, поданого ГСА, складається автоматна модель у вигляді графа переходів кінцевого автомата Мілі. Граф переходів подано мовою опису апаратури VHDL у формі двопроцесного автоматного шаблону. За графом переходів будується алгоритм діагностування пристрою управління за стратегією обходу всіх дуг графа, що гарантує його повноту.

Результати. На підставі алгоритму діагностування будується VHDL-модель апаратного пристрою діагностування. Верифікація моделі розробленого пристрою діагностування виконується 3 використанням системи моделювання Active-HDL. Синтез пристрою управління i пристрою діагностування виконується за допомогою САПР XILINX ISE. Результати синтезу показали, що апаратні витрати на пристрої управління i діагностування можна порівняти.

Висновки. Для зниження додаткових витрат апаратури на пристрій діагностування при автоматизованому проектуванні цифрових систем управління слід застосовувати методи тестопридатного проектування та вбудованого діагностування.

Практична цінність отриманих результатів полягає в аналізі схемної реалізації (синтезу) HDLмоделей пристрою керування (керуючого автомата КА i апаратних засобів діагностування (діагностичного автомата - пристрій діагностування ПД), дозволяє оцінити величину додаткових витрат апаратури за допомогою критерію Квайна. Аналіз додаткових витрат апаратури показав, що їх можна порівняти 3 апаратурними витратами на сам пристрій управління. 3 одного боку, це збільшує апаратурні витрати на цифрову систему керування в цілому, але, з іншого боку, при реалізації системи керування на ПЛІС, на кристалі, як правило, присутня незадіяна програмована логіка, яка може використовуватися під апаратуру діагностування.
Список літератури

1. Synchronizing Sequences For Verification Of Finite State Machines [Text] / M. A. Miroshnik, A. S. Shkil, A. S. Grebenyuk, E. N. Kulak, etc. // 9th IEEE International Conference on Dependable Systems, Services and Technologies (DESSERT'2018) May 24 - 27. 2018/5. - P. 226-230.

2. Проведення діагностичних експериментів в керуючих автоматах з використанням синхронізуючих послідовностей [Текст] / А. С. Шкіль, М. А. Мірошник, Ю. В. Пахомов, Д. Г. Караман // Радіотехніка та інформатика: наук.-техн. журнал. - 2018. - № 3. C. $43-52$.

3. Design automation of easy-tested digital finite state machines [Text] / M. A. Miroschnyk, A. S. Shkil, E. N. Kulak, etc. // Radio Electronics, Computer Science, Control: Zaporizhzhia National Technical University. 2018. - № 2. - P. 117-124.

4. Barcalov, A. Logic Synthesis for Finite State Machines Based on Linear Chains of States [Text] / A. Barkalov, L. Titarenko, J. Bieganowski. - Berlin: Springer, 2017. - $225 \mathrm{p}$.

5. Lorenzo Clemente, Wojciech Czerwi'nski, Slawomir Lasota, Charles Paperman. Regular Separability of Parikh Automata, June 20, 2017.

6. Solov'ev, V. V. Minimization of mealy finitestate machines by using the values of the output variables for state assignment [Text] / Journal of Computer and Systems Sciences International. - January 2017. - Vol. 56, Iss. 1. - P. 96-104.

7. Miroshnyk, M. A. Model of automated hardware diagnostics of remote energy systems management points [Text] / M. A. Miroshnyk, Y. V. Pakhomov // Світлотехніка та електроенергетика: міжнар. наук.техн. журнал. - 2017. - №3. - С. 3-9.

8. Solov'ev, V. V. Minimization of power consumption of finite-state machines by splitting their internal states [Text] / T. N. Grzes, V. V. Solov'ev // Journal of Computer and Systems Sciences International. 2015. - Vol. 54, No. 3. - P. 367-374.

\section{Мирошник М. А., Клименко Л. А. Методы автоматизированного компьютерного проектирования цифрового устройства локального управления.}

Аннотация. Представлен метод автоматизированного компьютерного проектирования цифрового устройства локального управления (регулирования). На основе упрощенного алгоритма функционирования системы, представленного ГСА, складывается автоматная модель в виде графа переходов конечного автомата Мили. Граф переходов представлен на языке описания аппаратуры VHDL в форме двупроцессного автоматного шаблона. По графу переходов строится алгоритм диагностики устройства управления по 
стратегии обхода всех дуг графа, что гарантирует его полноту. На основании алгоритма диагностирования строится VHDL-модель аппаратного устройства диагностирования. Верификация модели разработанного устройства диагностирования выполняется с использованием системы моделирования Active-HDL. Синтез устройства управления и устройства диагностирования выполняется с помощью CAПР XILINX ISE.

Ключевые слова: диагностические эксперименты, управляющий автомат, граф переходов, синхронизирующая последовательность, САПР, Active-HDL, XILINX ISE.

Miroschnyk M. A., Klimenko L. A. Methods of computer-aided design of a digital local control device.

Abstract. The work is devoted to the issues of improving the reliability of logical control systems in supply systems. The presented method of computer-aided computer design of a digital device for local control (regulation). Based on a simplified algorithm for the functioning of the system, represented by GSA, an automaton model in the form of the transition graph of the Mile finite automaton consists. The transition graph is presented in the VHDL hardware description language in the form of a dual-process automaton pattern. According to the transition graph, an algorithm for diagnosing the control device is constructed according to the strategy of bypassing all the arcs of the graph, which guarantees its completeness. Based on the diagnostic algorithm, the VHDL model of the hardware diagnostic device is built. To diagnose the control finite state machine, it was proposed to conduct a "nondestructive" diagnostic experiment on traversing all vertices (arcs) of state diagram using synchronization sequences. The verification of the model of the diagnostics device developed is performed using the Active-HDL simulation system. Synthesis of control device and device diagnostics is performed using.

To reduce the additional hardware costs for a device diagnosing in computer-aided design of digital control systems, methods of test-based design and built-in diagnostics should be used. The scientific novelty of the work consists in the further development of computeraided computer-aided design of a digital local control device. The practical value of the results is in analyzing the circuit implementation (synthesis) of HDL models of the control device (control machine) and diagnostic hardware (diagnostic machine - the diagnostic device allows you to estimate the amount of additional equipment costs using Quine's criterion and analyzing the additional equipment costs and showed that they can be compared to the hardware costs of the control device itself, on the one hand, this increases the hardware costs of the digital system Thread management in general, but on the other hand, the implementation of management systems on an FPGA, SoC, as a rule, there is an untapped programmable logic, which can be used by diagnostic equipment.

Keywords: diagnostic experiments, control machine, transition graph sync sequence, CAD, Active-HDL, XILINX ISE.

Надійшла 24.12.2018p.

Мірошник Марина Анатоліївна, доктор технічних наук, професор кафедри Спеціалізованих компютерних систем, Украӥнський державний університет залізничного транспорту, Харків, Украӥна. E-mail: miroshnyk@kart.edu.ua ORCID ID 0000-0002-22312529

Клименко Любов Анатоліївна, кандидат технічних наук, дочент кафедри СКС, Украӥнський державний університет залізничного транспорту, Харків, Україна. E-mail:1yubasha@email.ua

ORCID ID http://orcid.org/0000-0002-8252-7425

Miroshnyk Maryna Anatolijvna., doctor of technical science, professor of the Department of Computer Systems Ukrainian State University of Railway Transport, Kharkiv, Ukraine. E-mail: miroshnyk@kart.edu.ua ORCID ID http://orcid.org/0000-0002-2231-2529

Liybov Klymenko, Doctor of Philosophy, associate professor department of specialized computer systems, Ukrainian State University of Railway Transport, Kharkiv, Ukraine. E-mail: lyubasha@email.ua. ORCID ID http://orcid.org/0000-0002-8252-7425 